\title{
Activation of T Lymphocytes as a Novel Mechanism in Beta1-Adrenergic Receptor Autoantibody-Induced Cardiac Remodeling-Additional Information About TLR9 Involvement
}

\author{
Annekathrin Haberland ${ }^{1}$ (D) $\cdot$ Johannes Müller ${ }^{1} \cdot$ Katrin Wenzel $^{1}$
}

Published online: 18 March 2019

(C) The Author(s) 2019

Du et al. [1] with their recently published interesting investigations on T cell activation caused by beta1-adrenoceptor autoantibodies represent another piece of the puzzle in identifying the entire pathological way of action of these agonistic acting autoantibodies in the pathogenesis of heart disease.

These authors observed that, besides the already welldescribed activation of the beta1-adrenoceptors directly in the heart cells [2,3], these autoantibodies additionally activated beta1-adrenoceptors in T lymphocytes [1]. Via the latter, the autoantibodies caused IL-6 release which is, according to their results, a further contributing factor to the pathogenesis of heart failure. Their observation bridges heart failure to an immunological perspective, a perspective which was recently comprehensively reviewed by Alvarez and Briasoulis [4] including current and novel treatment strategies.

There is just one additional aspect we would like to bring up in this context. With respect to initial triggers of heart failure, Eriksson et al., when reporting about the "dendritic cell-induced autoimmune heart failure requires cooperation between adaptive and innate immunity," investigated the impact of TLR receptors as triggers but also sustainers ("myocarditis relapse") of heart failure in an animal model as early as 2003 [5]. A work, continued by Oka et al. in 2012, showing "that mitochondrial DNA that escapes from autophagy cell autonomously leads to Toll-like receptor (TLR) 9-mediated inflammatory responses in cardiomyocytes and is capable of inducing myocarditis, and dilated cardiomyopathy" [6].

Both studies together complete a general understanding of the effects of TLR9 on the initiation and subsequent mainte-

Annekathrin Haberland

haberland@berlincures.de

1 Berlin Cures GmbH, Berlin, Germany nance of heart failure that creates a vicious circle by making TLR9 essential in autoantibody formation [4], which in turn, stimulate receptors in heart cells and $\mathrm{T}$ lymphocytes [1].

It would be interesting to know in this context, if beta1autoantibody activated $\mathrm{T}$ cells would be able to act as stimulator of the beta1-autoantibody production, similar to the function of other T cell co-stimulatory factors which again include, e.g., TLR9 ligands [7], sustaining the vicious circle. If so, this would finally offer an explanation for the already observed long-lasting persistence of autoantibody absence after even a one-time removal only, as seen after immunoadsorption [8] and also already at the single application of the autoantibody neutralizer BC 007 (here, observation period of one month) [9]. One treatment would practically be enough to interrupt this cycle. $\mathrm{BC} 007$ is the broadband aptamer for the neutralization of heart failure relevant agonistic acting autoantibodies which attack essential heart and circulatory system-regulating receptors including the beta1-receptor $[9,10]$. Independent from an answer to this question, with the antibody neutralizer BC 007, the TLR9 pathway will additionally be counteracted [11]. In cells, overexpressing the human TLR9 receptor and a corresponding reporter protein, BC 007 pre-incubation was able to abrogate agonist-caused TLR9 stimulation (ODN 2006, InvivoGen).

$\mathrm{BC} 007$ is, therefore, able to break into this pathogenic vicious circle via autoantibody neutralization and TLR9 antagonism but would also always be able to act on both pathways alone. With the latter widening, the circle of patients who should benefit from a therapy also possibly including patients showing symptoms and TLR9 overexpression but no or not yet autoantibodies [12].

BC 007, currently under preparation for phase II of the heart failure efficacy testing, has already shown its autoantibody-neutralizing efficacy in humans besides its favorable side effect profile [9]. Derived from the good experiences made with the removal of these autoantibodies via 
immuoadsorption $[2,13]$, it is hoped that a huge number of heart failure patients will benefit from this novel causal treatment.

\section{Compliance with Ethical Standards}

Conflict of Interest A. Haberland, K. Wenzel, and J. Müller are employed by Berlin Cures. A. Haberland and J. Müller are shareholders of the Berlin Cures Holding AG. A. Haberland is an inventor of BC 007, and A. Haberland and $\mathrm{K}$. Wenzel are inventors of the BC 007s TLR9 inhibition. The authors have no other relevant affiliations or financial involvement with any organization or entity with a financial interest in or financial conflict with the subject or materials discussed in the manuscript apart from those which are disclosed.

Open Access This article is distributed under the terms of the Creative Commons Attribution 4.0 International License (http:// creativecommons.org/licenses/by/4.0/), which permits unrestricted use, distribution, and reproduction in any medium, provided you give appropriate credit to the original author(s) and the source, provide a link to the Creative Commons license, and indicate if changes were made.

\section{References}

1. Du Y, Li X, Yu H, Yan L, Lau WB, Zhang S, et al. Activation of T lymphocytes as a novel mechanism in beta1-adrenergic receptor autoantibody-induced cardiac remodeling. Cardiovasc Drugs Ther. 2019;33:149-61.

2. Dandel M, Wallukat G, Potapov E, Hetzer R. Role of $\beta_{1}$ adrenoceptor autoantibodies in the pathogenesis of dilated cardiomyopathy. Immunobiology. 2012;217:511-20.

3. Wallukat $\mathrm{G}$, Wollenberger A. Effects of the serum gamma globulin fraction of patients with allergic asthma and dilated cardiomyopathy on chronotropic beta adrenoceptor function in cultured neonatal rat heart myocytes. Biomed Biochim Acta. 1987;46: S634-9.

4. Alvarez P, Briasoulis A. Immune modulation in heart failure: the promise of novel biologics. Curr Treat Options Cardiovasc Med. 2018;20:26.

5. Eriksson U, Ricci R, Hunziker L, Kurrer MO, Oudit GY, Watts TH, et al. Dendritic cell-induced autoimmune heart failure requires cooperation between adaptive and innate immunity. Nat Med. 2003;9: 1484-90.

6. Oka T, Hikoso S, Yamaguchi O, Taneike M, Takeda T, Tamai T, et al. Mitochondrial DNA that escapes from autophagy causes inflammation and heart failure. Nature. 2012;485:251-5.

7. Rahman AH, Taylor DK, Turka LA. The contribution of direct TLR signaling to T cell responses. Immunol Res. 2009;45:25-36.

8. Dandel M, Wallukat G, Englert A, Lehmkuhl HB, Knosalla C, Hetzer R. Long-term benefits of immunoadsorption in $\beta(1)$ adrenoceptor autoantibody-positive transplant candidates with dilated cardiomyopathy. Eur J Heart Fail. 2012;14:1374-88.

9. Mueller J, Haberland A, Becker N-P, Wenzel K, Wallukat G, Goettel P, et al. The DNA-based therapeutic agent BC 007 completely neutralizes agonistic autoantibodies directed against $\beta 1$-adrenoceptors: results of a phase 1 trial. J Am Coll Cardiol. 2018;71:A645.

10. Haberland A, Holtzhauer M, Schlichtiger A, Bartel S, Schimke I, Müller J, et al. Aptamer BC 007 - a broad spectrum neutralizer of pathogenic autoantibodies against G-protein-coupled receptors. Eur J Pharmacol. 2016;789:37-45.

11. Haberland A, Wenzel K. (2016) Aptamers for use in inhibition and/ or suppression of TLR9 activation WO2018/095697, May 2018.

12. Hally KE, La Flamme AC, Larsen PD, Harding SA. Toll-like receptor 9 expression and activation in acute coronary syndrome patients on dual anti-platelet therapy. Thromb Res. 2016;148:89-95.

13. Müller J, Wallukat G, Dandel M, Bieda H, Brandes K, Spiegelsberger S, et al. Immunoglobulin adsorption in patients with idiopathic dilated cardiomyopathy. Circulation. 2000;101:385-91.

Publisher's Note Springer Nature remains neutral with regard to jurisdictional claims in published maps and institutional affiliations. 